\title{
Motivation and perseverance of women in education leadership in the United States of America
}

\author{
Marie Goretti Nakitende ${ }^{1}$ *
}

(C) Uganda Martyrs University

\begin{abstract}
This study examined executive women leaders in higher education administration in the United States of America. It examined factors influencing women to attain leadership positions. It also looked at the challenges facing female leaders and established strategies women use to overcome these challenges. A sample of 11 women leaders in higher education was selected purposively based on experience, seniority and roles. Multiple sources of data collection were utilised including interviewing, observation and document analysis, which served as a way of triangulation. The nature of the study was exploratory. The qualitative phenomenological method was utilised to organise and analyse the data. The researched data was collected from both primary and secondary sources such as journals, interviews and observations. Findings reveal that senior women leaders in higher education positions are intrinsically moved by a great desire to make a positive difference and a need to help others. External forces influencing women to leadership include mentoring, self-efficacy, networks, prior experience, leadership training, and career planning. The results indicated that the women desire is to achieve personal growth and development. The results are consistent with both leadership and motivation theories (Maslow, 1970; Burns, 1978; Bandura, 1997). The findings are limited to women leaders in the education sector; they cannot be generalised to other business sectors.
\end{abstract}

Key words $\cdot$ Female leaders $\cdot$ Motivation $\cdot$ Challenges and strategies $\cdot$ Higher education

\section{Introduction}

Throughout history, women have fought to improve their own lives and the lives of women who come after them. As educators, women challenged the comforts of familiarity to reach new understanding (Walton and McDade, 2001). It is important to ascertain experiences that inclined women to pursue leadership roles in higher education and comprehend what helped women to carry on and thrive in upper-level education administrative positions. It is also pertinent to discover ways that could increase women's aspirations and involvement in leadership. It is important to recognise women's undertakings to increase their visibility and open doors for them and future leaders.

\footnotetext{
${ }^{1}$ Uganda Martyrs University,*mnakitende@umu.ac.ug
} 
Traditionally, administration of higher education is a male-dominated field. However, starting with the first female president of the American Council on Education, to the first female and Hispanic president of Texas A\&M University, women have made some progress. The American Council on Education report (2012) shows women hold 57 percent of senior administrative positions in higher education in the United States of America (USA). In another report, the same council (2008) reported that the women's affirmative action, feminism and women's strong work ethic and abilities played a role in women's decisions to attain leadership and administrative positions. Women today have become more visible within the workforce; they have also increased their numbers in leadership and managerial roles.

West and Curtis (2006) noted that, the representation of women in higher learning institutions decreases as the level of academic rank increases. This trend is even reflected in other sectors of the economy. For instance, there are only 24 female Chief Executive Officers among the top 500 companies in the USA (Fortune 500, 2018). In politics, the situation is almost the same because out of the 195 countries in the world, 17 are lead by women. Women also hold $20 \%$ of seats in parliaments globally (Fairchild, 2014). Although the proportion of women in leadership roles has increased within the past decades, women remain vastly underrepresented at the highest organisational levels. Men are still viewed as business managers globally. Women generally make up the highest share of managers in human resources occupations and social and community services. This means men are more likely to be accelerated into leadership positions by means of glass escalators (Klenke, 2011).

Previous research shows that one of the main reasons that women are underrepresented in top leadership positions is that some people, both male and female, undervalue the effectiveness of a woman as a leader (Valdata et al, 2008; Eagly and Wood, 2012). In spite of the challenges still facing women and preventing them to achieve upper-level leadership positions, we need to recognise women's efforts and the contributions they have made to education leadership in order to get a better understanding of the experiences influencing and contributing to success of academia women in leadership. Those who manage to overcome barriers indicate that social and emotional support is very helpful to female leaders (Caliper, 2014).

American Council on Education (2012), Madsen (2007), and a national survey by the American Council on Education (2007) found that female presidents hold 23 percent of higher education institutions in USA. It was further discovered that majority of the female presidents were concentrated in community colleges and research universities. Women have made strides. For those who are aspiring for leadership, it is important to understanding women's experiences and how intrinsic and extrinsic motivation influences their decisions to join leadership roles.

Motivation is a complex phenomenon that cannot be fully explained by one person. Maslow (1970) believes motivation is the force, which moves individuals to act. Additionally, McKee and Phillips (2001) noted that motivation is an inner force, which drives, directs, reinforces, and sustains human behaviour. One researcher 
cannot fully explain what motivates and influences women to leadership roles. To understand better what influences and helps women succeed in leadership, Birnbaum and Umbach (2001) analysed data collected from a survey of 2,297 female university presidents, conducted in the United States. They found that $6.3 \%$ of the respondents got to leadership positions through a traditional career path, moving up through the academic ranks. In other words, to achieve and succeed in leadership you must plan, persist, and aspire for leadership or to achieve high-level positions you need to plan, be internally driven and determined to achieve high goals.

Educational institutions provide more opportunities for men and women, who may have potential and want to change their careers. This study provides strategies that can assist those who are interested in attaining more responsibilities in leadership. It also highlights the major challenges facing women in leadership to ensure that the information given can help you understand how women lead. It can also help those who are in career transition understand how to advance their careers to upper-level positions to develop essential skills and abilities required to succeed in leadership

\section{Women in higher education administration}

Traditionally, women have strived and gained leadership ranks in both government and business organisations. However, one area in which their contribution has not yet been fully acknowledged as a significant force is in decision making in educational institutions (American Council on Education, 2012; Madsen, 2007). In spite of their efforts and contributions to higher education, women continue to be underrepresented in administrative positions in academia. Accordingly, the previous researchers clearly show that oftentimes, women are appointed in part-time and non-tenure track positions (Valdata et al, 2008; Eagly, and Wood, 2012). This situation may also affect their career advancement.

The American Council on Education (2012) shows that the percentage of women in education administration rose from $23 \%$ to $26.4 \%$ in 2011 , a small rate compared to the number of women and universities. It should also be noted that women are least likely to head public higher education institutions. For instance, in the United States, female presidents are concentrated in private universities and community colleges. The underrepresentation of women in administrative positions, particularly in educational institutions is a waste of human resources and talent.

Women have great potential to empower and transform education systems. However, excluding them from leadership and administration responsibilities can have a significant impact on the development and sustainability of an institution. In order to attract many young people to assume leadership responsibilities, we need to recognise the accomplishments and successes of women in senior executive leadership positions.

The United States Census report (2013) revealed that out of the fourteen small businesses studied in 2013 as part of benchmarking, women hold 20\% of the top executive positions within each sector. Furthermore, the American College President 
study conducted in 2017, revealed that from 1,546 college leaders across the States studied, the whites are 83 percent and males are 70 percent and the percentage of women holding the top job at colleges and universities stood at 30 percent (Gagliardi et al., 2017).

Nonetheless, the largest percentage of female Chief Academic Officers CAOs is found among those with previous positions as department chairs and faculty members (43 percent), followed by previous positions as other academic officers (40 percent), non-academic officers (33 percent), and finally the CAOs and provosts stood at 29 percent, (Gagliardi et al., 2017). This means leading an institution of higher learning is not only difficult but it is also complicated.

Women have the possibility to rise to high-level positions but they face many obstacles. Despite their small numbers, women have made good advancement, yet little is known about their talents, characteristics, experiences, qualities, values, and ways of leading. Therefore, if you have been questioning, what influences women and contributes to their success in leadership this study provides factors that influence women's decisions to attain leadership roles. The study may not provide you with all the answers but it gives strategies and techniques that are showing women's ways of leading, particularly in higher educational institutions.

Previous research clearly shows that male behaviours and characteristics in leadership are used as a measure to assess female leaders' success and abilities (Wolverton, Bower, and Hyle, 2009). I believe that using such male-centric leadership models and norms limits women's aspirations. We need to recognise that women have the will power and essential qualities to improve not only their lives but also can transform the systems of higher education. For example, from the first women's rights movement to vote in 1920 , White (2003) proves to us that considerable efforts have been made through government regulations, affirmative action and education training to increase women's participation in the work force, leadership and management and many women have earned doctorate degrees.

Although previous research shows that the number of women in full professorship presidencies does not compare with those in higher education, women have made some good progress. A recent study by the American Council of Education (2012), notes that women obtain a majority of post-secondary degrees, they also occupy a big percentage of University presidents. Morley's (2013) report shows similar findings for senior leadership of educational institutions in the United Kingdom and European Union. Grove (2013) indicates that female graduates outnumber males at the undergraduate level, comprising 60 percent of that population, and make up 50 percent of early careers in academia.

Further reports show that in 2014, 59 percent of graduates were women, 51 percent of doctoral and first professional degrees students were women, but only 26 percent of higher education presidents were women (National Centre for Education Statistics, 2014). 
Several studies recognise the barriers restricting the advancement of women into leadership. Institutions need to promote a workplace environment that supports women and welcomes diverse leadership styles. It helps organisations to increase their profitability, performance, productivity, innovation, social responsibility and success (Supiano, 2014; Laursen and Austin, 2014).

The National Centre for Education Statistics, (2014) report clearly shows that by 2019, women will account for 59 percent of graduate enrolment and 61 percent of the total number of students enrolled for advanced degrees in the United States. This is a clue that women are advancing and getting well set academically. Therefore, creating a diverse and inclusive workforce is necessary to attract more graduates and encourage them to aspire to leadership.

\section{Motivation of women in leadership}

Previous researchers have recognised that more women than men are hired into parttime and non-tenure track positions (West and Curtis, 2006). In spite of that, we need to recognise their efforts and achievements in education leadership. There are many different reasons influencing women to lead. Some may look at leadership as an opportunity for personal growth and development. Others may look at it as a way to develop their competence and/or to help others achieve their goals. According to some of the recent reports, the rate of women in leadership is increasing. In the United States, for example, 26.4 percent of university presidents are women (American Council of Education, 2012). These are some of the experiences influencing and encouraging women to achieve leadership positions. For instance, in an interactive interviewing process with university women presidents, I found that career planning plays a role in advancement of women to leadership. Though some women just find themselves in leadership, the majority of those interviewed indicated that they passed through a traditional career path of academia. In reference to that, one woman illustrated:

I am the first-generation college student [in my family]. Neither one of my parents went beyond high school. I got married when I was quite young, and we had two children. I was a nurse at the time. In addition, I had a diploma in nursing. Therefore, when I had children, I took a clerical job. Then after some time, I realised that I needed to learn much about my profession. Therefore, I went to get a bachelor's degree. Therefore, when all this was all going on my children were still little. Therefore, my life was moving in different directions. Sometimes, I thought I could do without having a degree. I went on and started. I picked special classes in nursing critical care. From there, I started to do clinical teaching. With that in mind, I knew that I would be the person they come to, when people needed help. At that time, my husband was ill. So, during that time, as I was torn between my families and starting a master's degree. I thought of 
two things. First, I will need a Master's degree to do things that I needed to do. Secondly, as things were going, I thought that I might be a support of my family singly. So, what happened, my husband did pass away. But I got a doctorate before that. Neither my husband nor my parents pushed me to go to college. On the other hand, my parents were very happy for me. So, it was me. There was a driving force within me internally.

When one looks and reflects upon the lived experiences of women leaders in education, they can see how institutions can provide more opportunities for women's career advancement. Therefore, this study aims to encourage those interested in leadership to consider and apply to work in educational institutions. Further results revealed that career planning and goal setting is vital to leadership. For example, in reflection to her career, another woman explained:

\begin{abstract}
After teaching for about four years at the MK public schools, I started thinking about other ways I could make a difference in the lives of children. I started thinking about being a college professor. I knew that if I was a college professor, I could have a greater impact on many lives. At the same time, while thinking about being a college professor, I got a call from someone for a faculty open position at SFC University. I accepted and took the job offer. My first role was to teach educators how to be great teachers. Another objective was to check out the $\mathrm{PhD}$ programme without knowing that I was really going to get a PhD in leadership.
\end{abstract}

Accordingly, Gumelch (2000) stated that career planning plays a fundamental role in achieving high goals. In other words, to achieve higher-level positions in academia, you may need to plan and set clear goals. This means setting goals can motivate you to work hard and achieve set goals.

This study does not only show how women get into leadership but it also encourages those interested in career development to advance to upper-level positions be determined and committed. For instance, while sharing her experiences in leadership, Joan Lead, who was a college president for 35 years, stated, "knowing what you want to do and make the work that you do meaningful is energising." When asked to speak about her career background, she explained how she got integrated into leadership by demonstrating her ability and knowledge in higher education. Filled with much confidence and satisfaction, she woman explained:

I have been with SFC University, I believe for about 38 years. I began as a faculty member. I served in various positions, first, as a faculty lecturer. Then, I became the department faculty chair for a while in the department of Special Education. At that same time, I was also the Chair of Faculty Board, and then later, I became the chair of the faculty senate. At a certain time, the vice president for academic affairs left the university, and I was asked to assume the position. I agreed to do it for a few years. 


\begin{abstract}
But, after serving as the vice president for academic affairs for a while, I was asked to stay on. In higher education, it is very difficult to have two new people. So, I stayed on and ended up in the position for 18 years, yet initially I had said that I would only do it for one year.
\end{abstract}

This woman's story demonstrates a high sense of self-efficacy and confidence. She believes in her ability to make a positive difference, wants to help others achieve and likes to inspire young professionals and show them how to be good citizens. Interestingly, after serving in higher education leadership for 18 years as Vice president, she moved back to the faculty line, and accepted responsibility of teaching at the graduate and undergraduate levels.

The career paths to women in leadership are quite different. One knew early that she desired an administrative position and focused her efforts and career plans on higher education leadership. She openly stated, "I carefully sought out and carefully looked for opportunity to gain experience." The fact that she desired to become an administrator she attributes her leadership success, in part, to her education training, prior experience, and mentors. Achieving high goals does not end with training; you must have the desire and passion.

Another woman contended, "I never had a plan to become a president. I simply fell into positions." She simply welcomed opportunities as they come. However, she added that, she did not complain or think of leadership as a challenge, due to her desire to help others and commitment to make a difference. One summed up her influence, "I had a passion about higher education and the fact that I am doing my work well, I know that I could do a good job and make a difference in others' lives." In terms of leadership abilities and attributes, most of them highlighted selfconfidence, determination, self-awareness, commitment and passion. Their selfknowledge and desire to serve contributed a lot to the success of women higher education administration. Women in higher education administration have a strong sense of self-confidence. One respondent argued that, she wanted to be in a position where she can have a voice, to help, empower, and make things better. According to Senge (1990), this form of leadership is called servant leadership. It begins with the natural feeling that one wants to serve first.

Therefore, career paths of women leaders in higher education should be viewed not only as a matter of changing from one position to the next, but also as a mixture of different interests and things. It includes their passion, belief in their ability to influence, and a desire to inspire and make a positive difference. Previous respondents expressed how they find meaning in what they do. Some women leaders interviewed see their roles as a responsibility, to teach and inspire others to achieve goals. In addition, one woman summarised her career paths experience saying that it is good for her to be back in the classroom. She went further to explain:

I try to inspire our students. Inspire out of our mission, and I tell them our core values. Certainly, I try to provide them with the knowledge that they 
need to be a successful teacher in the classroom. That is what is going to help young teachers to create a great culture in a school. Many of our school do have a great culture but others do not. Therefore, teachers must care for their students.

These findings reveal that the women in higher education leadership were intrinsically moved by a great desire to make a positive difference, to help others, to achieve personal growth and development, and to create and support the organisation's mission and vision. An array of extrinsic motivational factors such as academic training and qualifications, mentors, role models, affiliation, promotion, feedback, recognition, and family support were also identified. These factors concurred with those established by previous scholars. Maslow (1970) believes motivation is a force, which moves individuals to act. McKee and Phillips (2001) view motivation as an inner force that drives, directs, reinforces, and sustains human behaviour. In other words, there are many factors that influence and contribute to the level of effort women are willing to expend to achieve high-level positions in higher education. Figure 1 summarises the experiences and variables identified regarding experiences that influenced women to obtain leadership roles in the institutions of higher education in the USA. 


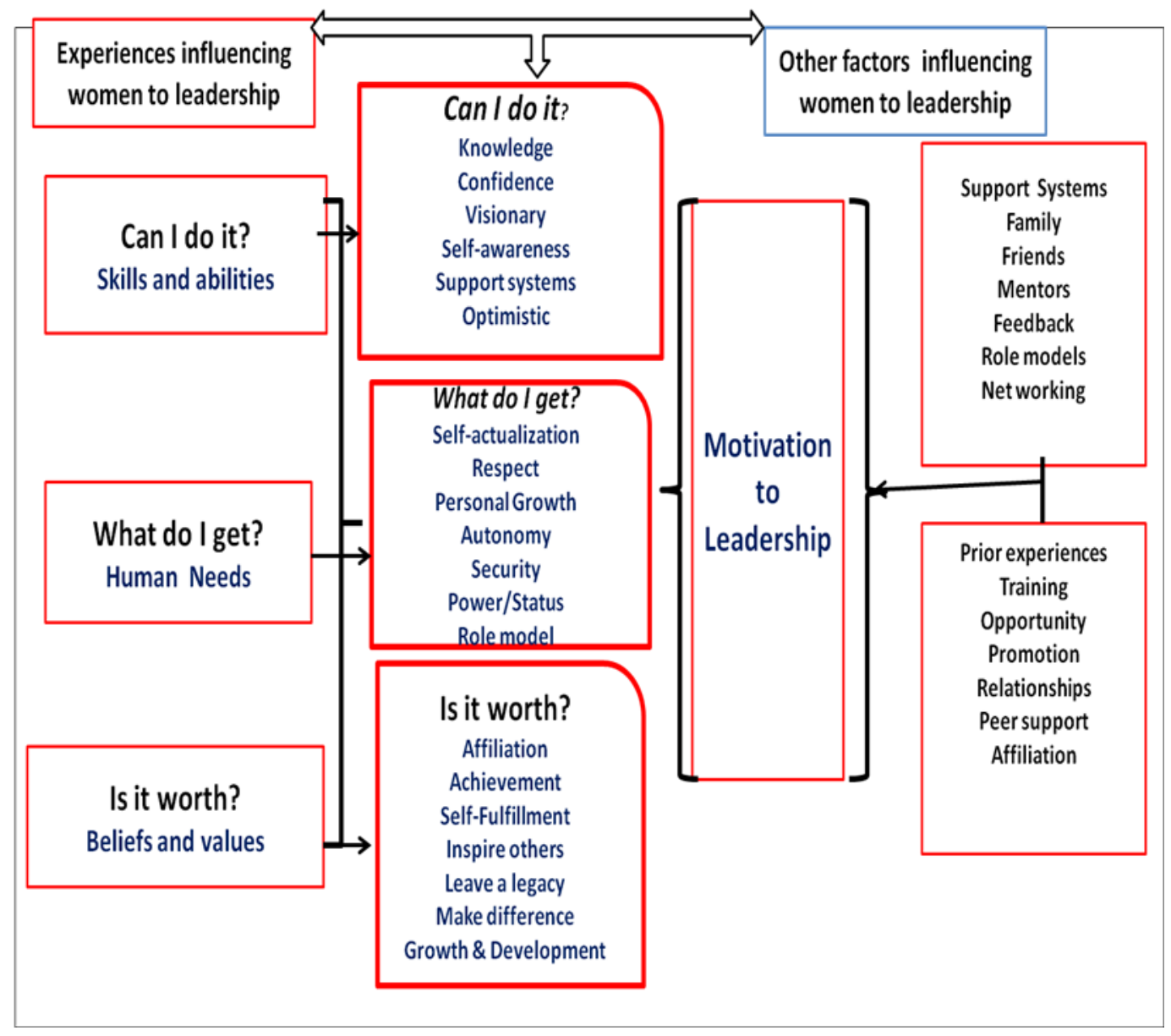

Figure 1: Experiences Influencing Women to Education Leadership

As Figure 1 shows, all the women explained what influenced their career decisions to join higher education leadership. This includes: skills and abilities, Human Needs, and Experiences (beliefs and values). There are many different factors influencing women to assume leadership roles in education.

A case in point is one of the respondents, who said,

I liked to be part of an academy, am interested in the well-being of others. I like to look to the future, possibilities, probing, and working with people who enjoy helping others, and moving together. 
Others felt that being in a high level of leadership gives a person freedom to go ahead and do what they want to bring about positive change. In addition, another woman explained that she wanted to be in a place where she can come alongside other people, to help them learn, grow, and develop. She believes that working in a school environment gives her the opportunity to grow, learn, and develop.

One of the respondents summarised what motivates and influences some women to academic leadership by saying that, "In schools you are always learning, growing, and developing. And so, that was my intention of going to higher education leadership." These experiences provide us with great insights and lessons from their lived experiences

For instance, when I asked one of the respondents who had spent 12 years as a university president what influenced her career choice, she replied that:

I had not applied for the job, but I accepted it because it was worthwhile. I served on the board of trustees and so, when I was asked if I would accept the job, and be the executive vice president of the university, I said, "Yes," because of my faith in God. I think my faith in God has been the core of what I do. What I do I have always worked in the non-profit world and it is always important for me to do the work that is important and matters most in areas that I can see [as having a] direct impact on other people.

She added:

I love the culture here. I think the people at the school truly understand that sense of service and commitment to others. Moreover, that I think gives me a great sense of joy. Therefore, for me what I love most about my work are really, the people. I love watching the progress of students and seeing students grow and develop.

Again, when talking about the value or what influenced women to join higher education administration, another woman responded by saying:

I enjoy developing people. I enjoy the notion of putting energy into helping other people grow and seeing them thrive. And that is my belief about my leadership. So, the role of the leader is to create an environment, not only the physical environment, but total environment so that individuals can do their best.

However, to understand better the experiences, which influenced women pursue leadership positions in higher education, it was important to explore intrinsic and extrinsic motivation. Ryan and Deci (2000) theorised that intrinsic motivation is a force derived from executing the activity itself, because the job is inherently interesting or gives the person a certain level of fulfilment and satisfaction. On the 
other hand, extrinsic motivation comes from external outcomes such as goals and rewards. Herzberg (1966) show that conditions at the workplace or the job itself must be pleasing and rewarding to a certain level or degree to increase and sustain individuals' motivation at the workplace. Maslow (1970) theorised that individuals are driven by a desire to satisfy their unmet needs such as physiological needs, social needs, growth, and self-actualisation among other self-related interests needs. However, if a lecturer or staff is not satisfied at faculty level position, it may be very difficult to influence that person to assume more responsibilities and or attract young academicians to participate in administrative tasks.

It is very important to recognise what motivates individuals. This study looks at both internal and external factors influencing women to assume leadership roles in education. Understanding how individuals' interests, desires, goals, values, beliefs, attitudes, and choices motivate is essential to leadership success. For example, the interview findings revealed that things such as competence, achievement, affiliation, self-esteem, values, growth, and making a difference play a fundamental role in the aspirations of women to join educational leadership. This means, motivation can be in the action itself. A sense of fulfilment or the joy that you get in doing the work or performing a certain task can intrinsically be motivating. Intrinsic motivation is the act of doing the task simply for the enjoyment rather than the value of the activity itself. Therefore, what makes leadership intrinsically motivating are the achievements, sense of fulfilment, self-actualisation, confidence, and competence that individual leaders get in doing the job.

On the contrary, to understand better the difference between intrinsic and extrinsic motivation, we need to ask ourselves, why do we do the things we do? Alternatively, what is it that drives our behaviours? In this case, those who are extrinsically motivated to achieve leadership roles are influenced by a desire to gain a physical reward or avoid an unfavourable outcome. This means some people are engaging in academic leadership not because they enjoy it or because they find it satisfying, but in order to get something in return or avoid something unpleasant. In this study, women in academic leadership are not only influenced by self-actualisation, but also, the mentors, relationships, salary, prior experiences and promotion were found to be extrinsically motivating. The next section provides a model of both internal and external experiences found to be motivating to leaders of institutions of higher learning, in particular women. Figure 2 presents intrinsic and extrinsic motivators influencing women into leadership. 


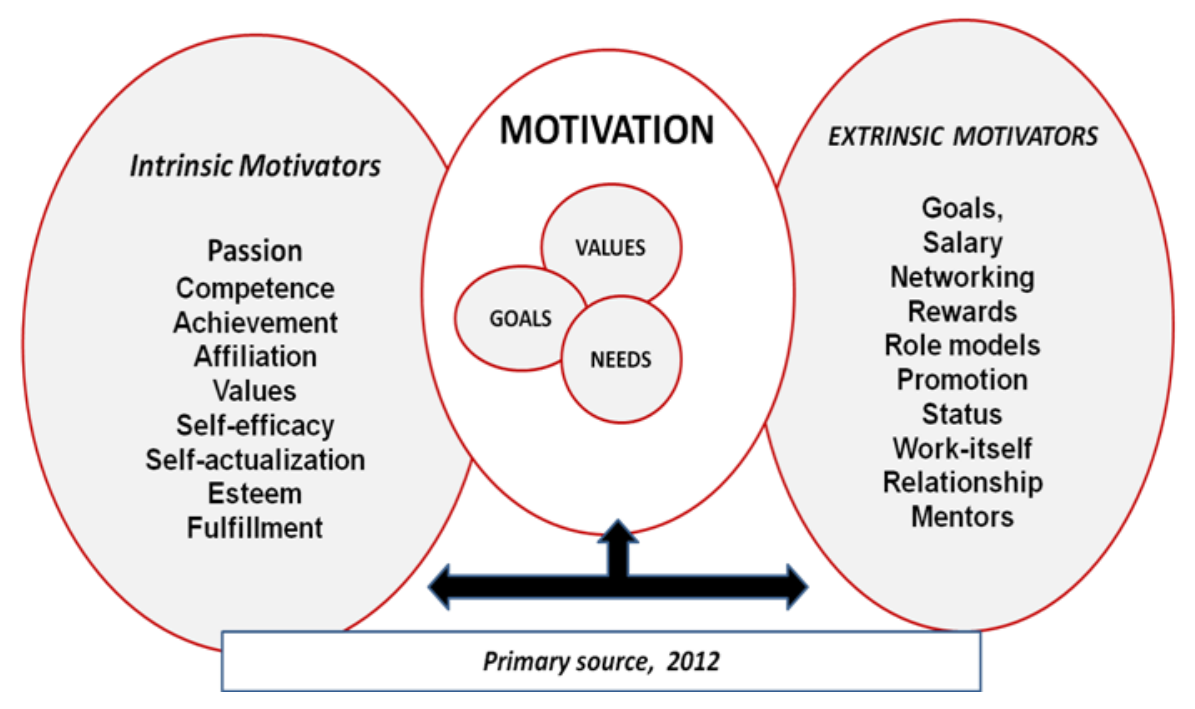

Figure 2: Intrinsic and Extrinsic Motivators

However, Bandura (1997) stated that a person with a strong self-efficacy sees challenges as opportunities to master. In other words, self-efficacy is one's belief in their ability to succeed in specific situations or accomplish a task. This means a person's sense of self-efficacy can play a major role in how one approaches goals, tasks, and challenges. In spite of various challenges facing women leaders, this study clearly shows us that self-efficacy can help a person persevere and succeed in highlevel positions.

However, self-efficacy alone is not enough; you must work hard, be determined and committed to achieve. Like women in this study, to be extrinsically motivated, the person must believe that their efforts will lead to desired outcomes. That is to say, fulfilment or self-actualisation also plays a role in career advancement of women leaders. It energises a person and influences them to persist and endure in difficult times.

Accordingly, as this study shows, majority of women in academia can be viewed as self-actualised leaders. They view their jobs with a continual sense of appreciation, wonder, and awe. Their sense of self-fulfilment and high level of self-actualisation intrinsically inspires and attracts them to seek more responsibilities and to assume leadership tasks. Self-actualisation may be difficult to test scientifically. However, as Kouzes and Posner (2007) argue, leaders want to do something significant, to 
accomplish something that no one else has yet achieved. In this case, women education leadership is no exception.

It is not a secret; women have historically struggled to overcome their barriers to achieving upper-level positions of leadership. Around the world, women now have more decision-making power and influence over social, political and economic life, than ever before. However, progress is uneven both across and within the education sector. This study presents influential factors behind women's careers and ways to increase their participation in leadership positions.

According to the results of the study, it was found that society, organisational culture, and individual perceptions and competences all play a role in women's career development and representation in leadership positions. Organisations make the direct decision on promoting female leadership through recruiting and offering career advancement. In this study, the researcher sought to understand what influences them and helps them move up to the top of the ladder to attain university presidency. When I think about women in education leadership or working in executive positions, the concept of a glass ceiling often comes up. Oakley (2000) defines a glass ceiling as barriers which women face, or have faced, in the business world. The glass ceiling is often found at the top of the hierarchy in an organisation and prevents women from achieving the same positions as men.

Some people may think that the glass ceiling has been already shattered and others argue that women are now facing a glass labyrinth. Women have the possibility to rise to higher positions but they face many obstacles on their way, instead of getting ahead straightforward as men often do (Oakley, 2000). In the United States, both men and women are well educated. Women can choose to have a career and family. Nonetheless, like any other developing country in Africa, there is still a salary gap between women and men's earning. In addition to that, women in leadership often face negative attitudes and discrimination. In spite of their efforts to advance their careers and achieve advanced degrees, the number of female leaders is still low.

The author decided to research this topic to understand well the main factors that influence women's rise to leadership positions. The author also looked at the issues affecting female leaders and identified ways that can help to increase the number of women in leadership positions.

\section{Theoretical framework}

In order to understand well this study, the theory of leadership is explained. However, since the concept of leadership is broad, the concentration will be placed on the theory of female leadership. Therefore, the basic concepts such as leadership, femininity and masculinity are explained in relation to the topic in order to examine the main factors influencing women to leadership. The meaning of careers will also be explained because it is an important concept of this study. To form the theory part of the study, 
data were collected from primary and secondary sources using interviews, books and internet.

\section{Trait theory of leadership}

Leadership is defined in various ways by different scholars. A leader has the ability to influence other individuals towards achievement of a vision or set of goals. According to Kouzes and Posner (2012), leadership involves various theories and styles. A review of the leadership literature on traits theory reveal that inherit qualities and traits play a role in leadership. For instance, the leadership of great leaders such as Mahatma Gandhi, Margaret Thatcher and Nelson Mandela is based on their qualities and traits. The trait theory assumes that leaders are born with qualities and traits in common such as ambition, perseverance, and intelligence among others that differentiates them from non-leaders (Robbins, Judge, and Sanghi, 2007).

\section{Behavioural theories}

Theoretically, the assumption behind traits approach is that leaders are born and not made. The behavioural theories assume that a leadership skill is developed through learning and experience. In other words, the trait theory concentrates on what the characteristics of leaders while the behavioural theories look on what the leaders do.

Furthermore, according to the contemporary theories, the Contingency/Situational Theories assumes that the success of a leader does not depend upon the qualities, traits and behaviour of a leader alone. In other words, situation in which a leader exhibits her/his skills, traits and behaviour matters, because some style of leadership may not be suitable for different situations (Kuchynkova, 2013). It is assumed that a leader can follow only a particular style in any given situation and the theory suggests change of a leader to fit a situation Therefore, the effectiveness of a leadership style depends upon a leader's ability, skills and adaptability to the different situations.

\section{Transformational theory of leadership}

Further theories reveal that transformational leaders pay attention to the developmental needs and concerns of the followers. They inspire and motivate their followers towards achievement of set goals of the organisation. In this form of leadership, the leaders act as role models for their subordinates and they show high level of ethical standards to gain respect and trust. This theory assumes that acting as role models can lead to success in leadership roles. Transformational leaders are empathetic. They listen and pay more attention to the individual needs so as to achieve success (Kuchynkova, 2013).

Generally, these theories offer a useful framework for understanding the women's leadership styles. The trait theory, contingency/situation theories, behavioural theories 
and transformational theory of leadership enhance our understanding of effective leadership effectiveness. Leadership can be defined in many different ways. Leadership is broad and changes over time. Therefore, we cannot use one definition or theory of leadership, as if it applies to all situations. However, to understand what influences women to leadership and what female leadership means, the nature of female leadership will be explained in the next section.

There is a huge literature on leadership that deals with different models or styles of leadership (Carter and Greer, 2013). According to Kim and Cook (2012) women leadership styles are viewed as a matter of equality and the right to have the same opportunities as the men. According to Batliwala (2011), feminist approaches to leadership came to advance gender equality in positions of power, to create structures that would stop the social injustices and discrimination suffered by women throughout the world. According to the women leaders' stories, the feminine characteristic is valuable in the work environment. Nonetheless, leadership should not be differentiated as female leadership at all. Leadership can be viewed as a tool or a process of influencing people to achieve set goals. The different styles of leadership derive from motivation, goals and the nature of the work or organisation. Therefore, women and men approach leadership differently.

\section{Career paths of female leaders}

According to Daft, Kendrick and Vershinina (2010), leadership comprises of three aspects: people, goals and influence. Leadership is influential action in itself. It may be used as a tool to achieve one's goals. Leadership is people-driven and the ability to inspire people helps a leader to achieve the set goals of an organisation. Leadership can be seen as a tool of self-motivation or process of motivating others. The motivation aims to achieve particular goals by the action itself or the activity done. The different styles of leadership derive from different ways of motivation, different kinds of goals and the nature of the work or experience lived (Hannagan, 2008). For this reason, leaders set the direction for others to move forward to the future and they motivate them to reach the set goals through a certain way of functioning or acting. Great leaders do not just happen. Leadership is a process; it may be learned and developed through experiences. In the next section, the author discusses the role of planning to career advancement of women to leadership.

Traditionally, a career had a more straightforward structure, for instance, people who are loyal to a company or an organisation could build their career inside that organisation. However, today, career has a more flexible structure. The study's results show us that it is possible to move up to higher positions and then go back to a less demanding position, and again later move up again. This clearly shows that people do not only want a job or a career for the sake of it, but the experiences must be enriching and fulfilling to the person (Airo, Rantanen and Salmela 2008). 
Further results of the study indicate that educational choices, the amount and nature of education, also play a role in our career paths. The first job after graduation is often seen as coincidental since graduates tend to apply to many different kinds of jobs. It may not match the education the person has completed or the idea of an ideal job one wants. Similarly, men and women have very different views on what they want to do after graduation and how they want to pursue their careers. Some may aim high from early on, and some just want to gain working experience before pursuing positions that are more challenging. For example, while reflecting on what influenced women to join into education leadership, a woman openly shared her story:

I am a people person with a social justice mindset. So, what I noticed in the health care profession at that time when Health Maintenance Organisation [HMO] became part of the typical insurance package, is that health care workers minimise direct patient contact for specialised services to decrease medical costs. Then, I began thinking about another career while acting as an activist in the community.

Traditionally, leadership has been viewed as a man's job simply because the nature and style of leadership has been very masculine. Leadership used to be vertical and more hierarchical. In the traditional way of leading, problem solving and setting goals was the most important thing. There has not been room for emotions or feminine behaviour. According to Lahti's (2013) study on stereotypes of women, female leaders are judged easily when they make mistakes. Female leaders have often to prove themselves. Women should not be expected to act differently than men, but rather female leaders must be able to act effectively according to the situations. In spite of all these stereotype characteristics, we need to recognise the efforts of women and support them to achieve their full potential. Some people may be more gifted than others may; however, promoting a work environment that supports young leaders is essential to men and women in leadership.

For instance, while reflecting on her career path Francis Xavier stated that:

I was always busy trying to do what I believe helps to create a better society. I wanted to be part of the solution, trying to make a difference, as opposed to just saying it is not right, which is part of the problem. This is when I discovered my calling. I wanted to be a part of helping to develop young people as potential leaders, developing into good citizens. Therefore, I knew that education was the key to my personal development and my ability to impact young leaders. This inspired me to get my teaching license, my master's degree, and finally my doctorate.

This story and many other experiences of women shows us how human needs differ from one person to another. Thus, when using extrinsic motivational factors, we need to remember that extrinsic variables may motivate some individuals but not all. 
Therefore, recognising the needs, values and beliefs influencing individual persons to do certain tasks is important for their retention. In other words, finding meaning in doing the work itself is important for increasing the individual's motivation.

\section{Challenges overcome by female leaders}

Traditionally, society restricted leadership to the male population. Leadership and management tasks were originally associated with masculine qualities and gender differences (Hyde and Kling, 2001). Society ascribed a woman's place to her home, caring for the husband and children, as opposed to the work place. Traditionally, colleges and universities prefer female presidents to be married. These are some of the obstacles preventing women from career advancement.

In addition, the role of men is to support their families while the role of women is to take care of their children and home. Since everyone has his or her individual characteristics and strengths, stereotyping should be avoided. Stereotyping slows down change and can act as a major obstacle when it comes to women's career possibilities. Women and men think in different ways, emphasise different aspects and approach problems in certain ways. Therefore, stereotyping men as more efficient underestimates the value of women qualities. Figure 3, presents a mode of various barriers female leaders face and certain strategies employed by women to overcome their challenges. 


\section{Barriers Overcome and Strategies employed by Women leaders}

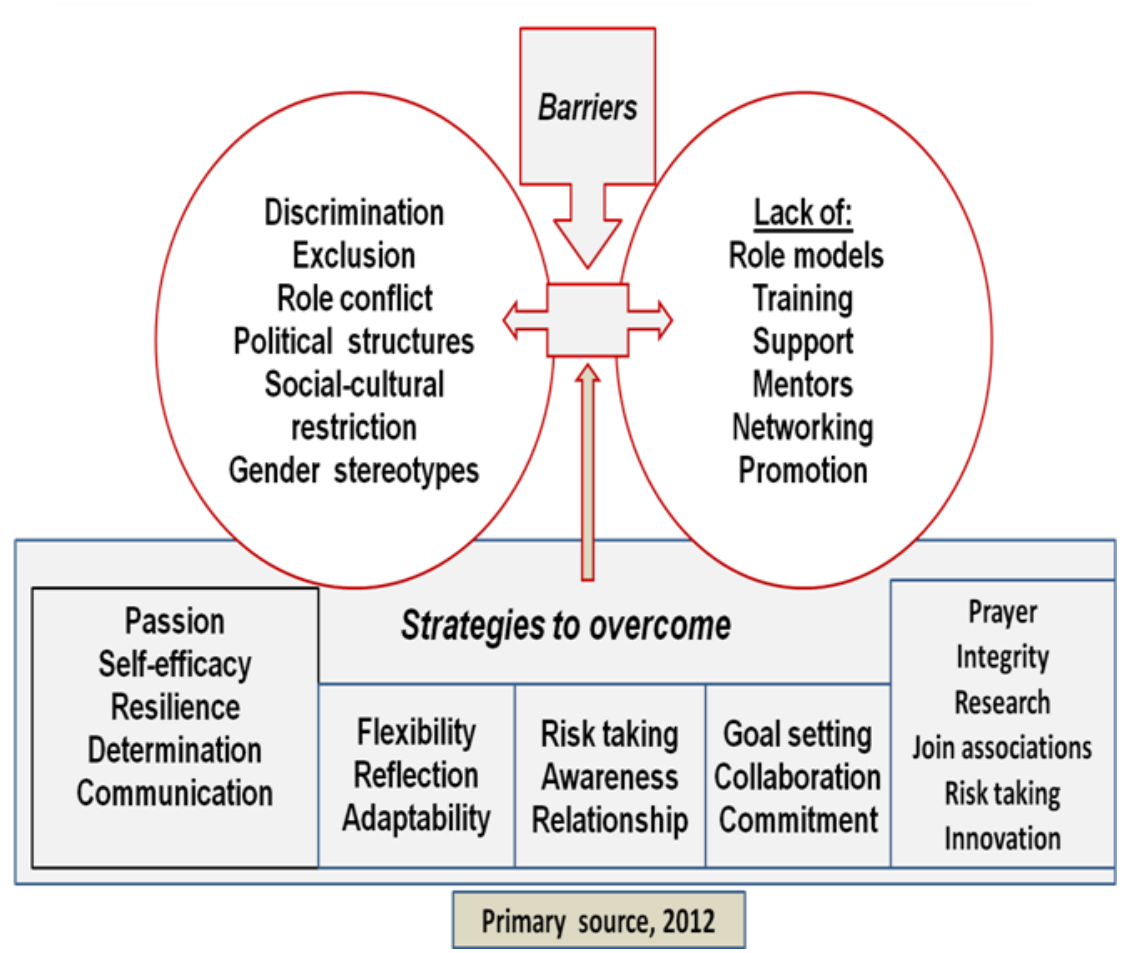

Figure 3: Leadership Strategies

As Figure 3 shows, many women in leadership positions still suffer from a narrowly defined leader image, gender stereo-types, double standards, exclusion from informal networks, negative attitudes and lack of work-related assistance and mentoring (Bilen-Green, Froelich, and Jacobson, 2008). There are many undetectable barriers produced by individuals' negative attitudes, societal beliefs and organisational prejudices. All these continue to promote the glass ceiling (Oakley, 2000). These elements clearly show how women juggle among different forces. The beliefs one may have about female leaders demonstrate what we think they are, and what we think they should be.

Despite their challenges, it should be noted that being optimistic or maintaining a positive attitude, could help young leaders to persist and persevere in difficult times. In fact, achieving high-level positions requires a person to be determined and to keep on trying, no matter how many times you may be discouraged. Career advancement requires a person to take a risk, persist and be determined to achieve the set goals. As the study results revealed, female leaders face problems and obstacles when they are in the decision-making process. These obstacles are often created by the differences in 
leadership styles, which lead to misunderstandings, mistrust, clashes and conflicts. However, most of the barriers women face today are more likely to result from gender-based preferences in recruitment, hiring decisions and work assignments, lack of effective mentorships, and lack of leadership development and experience. With men holding most positions on governing boards of higher education, preconceived notions, bias and inexperience affect the consideration of women candidates (Baltodano et al., 2012). Nevertheless, women leaders need to remain positive regardless of the extreme challenges they face.

\section{Strategies to leadership success}

Barsh, Cranston and Lewis, (2011), show us that to achieve high-level positions and be successful in leadership roles; five dimensions can be used. These dimensions include: a) having a strong sense of meaning, namely doing something that you enjoy doing, can inspire and influence others to achieve high goals, in this case, the women. b) Managing energy is about knowing where your energy comes from, where it goes, and what you can do to remain motivated. c) Positive framing is about maintaining a positive attitude and being open to other perspectives. In other words, to be successful in leadership roles, you must adopt a more constructive way of looking at life and the world around you. d) Making connections shows us the role of networking in leadership. In other words, identifying key people who can advise and assist us in different situations is important for our career advancement. The study results show how women can use networking to develop and advance their careers. e) Participation in other activities is concerned with participation in different activities, which can help those who are interested in career advancement to acquire basic knowledge and skills required to succeed in high-level positions. However, one must be determined and optimistic, and internally be driven to achieve the set goals (Ryan and Deci, 2000).

\section{State of women in education leadership}

Traditionally, men are considered more aggressive while women are seen as nurturing in nature. Different stereotypes of women and men's characteristics and roles in the society still exist strongly. This does not mean that women lack competence or expertise when it comes to assuming high-level positions. Although the number of female leaders is low in many parts of the world, West and Curtis (2006) indicate that the representation of women in higher education administration decreases as the level of academic rank increases. Women are often appointed at instructor/lecturer ranks and are less likely to be hired and/or promoted to higher administrative positions. Accordingly, the American College Presidents' report presented by Kim and Cook (2012) shows that out of all the female presidencies in American colleges and universities, $85 \%$ of women presidencies are white, $6 \%$ are African American, $4 \%$ are 
Hispanic, 2\% are Asian American and only 1\% are native American. As the statistics indicate, there is a sizeable gap and disparity of women in education leadership.

Oakley (2000) studied women's career paths and found that gender bias described in recruitment, selection, evaluation, and promotion processes play a big role in blocking women's advancement to upper positions. In spite of that, locus control, which refers to a person's ability to internalise the conditions in the environment, is important. A thorough discussion with 11 female leaders clearly shows us that, locus control helps to increase their confidence and chances of success in leadership. Kouzes and Posner (2007) suggested that finding something that one truly believes in is important because it help a person to think and reflect upon his/her work while striving to attain set goals. This means, people who are internally driven will keep working toward a result even if there is no reward. Nevertheless, those who are externally motivated or controlled by rewards are likely to stop trying once the rewards are removed, and some people choose to give up the tasks, especially when they come across a challenging situation.

Young and McLeod (2001) assert that, what influences women to assume leadership responsibilities depends on many different factors; some of these may include prior experiences, goal setting, and mentors among others. Nevertheless, the study results show that the major things that influence women to leadership include making a difference, helping others, serving, and having the autonomy to make decisions and solve problems. These elements are very important to perseverance of women in leadership. However, other results revealed that a few women leaders were not well prepared because some even fail to set goals for their development. Still, they demonstrated a strong sense of self-efficacy. Efficacy refers to people's belief in their capabilities to do the job. It contributes to the motivation, level of effort, and perseverance of the person in the face of difficulties. Bandur and Locke (2003) noted that people who have a strong belief in their capabilities see challenge as opportunities to learn and develop, while those who doubt their capacity to do the task shy away from challenging tasks because they see them as a threat. Self-efficacy is essential for career advancement and success in leadership.

Oakley (2000) argues that women leaders behave like men, they find themselves in a double bind, a behavioural norm that creates a difficult situation no matter what one does. Despite their challenges, all women leaders expressed that to be an effective leader one needs to be confident and resilient. Figure 3 serves as a model; it highlights the different barriers that women face. It also provides various strategies they employ to overcome these barriers.

\section{Women leadership styles}

A leader is someone who exercises power or authority over other people. Leadership entails being in charge of other people in multiple ways. It consists of influencing, motivating, organising, and coordinating the work of others. Therefore, this section 
presents leadership styles that women use to influence others to achieve their goals. Many times female leaders face legitimacy problems, because of employees resisting or judging their leadership. Eagly and Carli (2007) posit that female leaders use a more democratic and participative leadership style to earn legitimacy and to avoid resistance from subordinates. In spite of their differences, female leaders emphasise both interpersonal relations and task accomplishment. Harrow (1993) states that effective leaders take every opportunity to practice and reflect upon leadership skills. These skills include communication, negotiation, analytical thinking, decisionmaking, conflict resolution, political posturing, and analysis. The study results also found that women exercise leadership in a more constructive way. They encourage creativity and challenge the status-quo. They are interested in activities that are focused on bringing about change and positively impacting people's lives. They demonstrate a strong desire to serve and to make change. They see themselves as an agent of organisational change.

McClellan and Chrisman (2008) found that women develop leadership behaviours through practice and taking risks. They use their values and beliefs as a mechanism to strengthen them. They are very resilient, compassionate, self-determined, patient and optimistic. Resiliency is a person's ability to adapt, persist, and endure in the midst of hardships. Lapovsky's (2014), study about female leaders' career paths found that women use reflection and self-assessment as tools to analyse difficult situations, and find better ways to energise the self, transform and make positive change. As expressed in the study results, female leaders examine their experiences to identify new ways of solving problems. While completing tasks, their focus is always on development and mentoring others. As the study results have shown, female leaders demonstrate a transformational form of leadership. Transformational leaders demonstrate qualities that motivate and influence others to achieve. They communicate their values, purposes and the importance of the organisation's mission. Female leaders exhibit optimism and excitement about goals and plans.

Kouzes and Posner (2007) believe that values influence every aspect of our lives: our moral judgments and relationship with others, our commitment to personal and organisational goals are all influenced by values and beliefs that we hold. Therefore, promoting a safe and learning environment can encourage individuals to express their beliefs and values openly.

Eagly, Johanessen-Schmidt and van Engen (2003) performed an important metaanalysis comparing women and men with respect to their transformational, transactional and laissez-faire leadership styles. Surprisingly, it was found that female leaders are somewhat more transformational than male leaders, particularly in supportgiving and motivating followers.

In reference to communication, it was found that female leaders use a relation way of communicating. This means that they focus on strengthening the relationships between people, creating team spirit and equality. On the other hand, men use a 
vertical way of communicating. This form of communication emphasises authority or information flows from top downwards.

The reason why leadership has traditionally been considered a man's job is that the nature and style of leadership has been very masculine. Unfortunately, some female leaders also choose to behave more like men to gain credibility, authority, and be accepted. It should be noted that being a woman does not affect the capability of a person to execute certain tasks or the kind of jobs one can have. Although female leaders are under-represented in higher learning institutions, their accomplishments create opportunities for new graduates to consider and apply for more responsibilities in leadership.

\section{Recommendations}

Institutions should create a learning environment and support systems for women to compensate for the obstacles they are still facing. In addition, institutions need to promote women advancement to close the gender gap and diversify the leadership in higher learning institutions. More still, education institutions should provide more opportunities to students to develop leadership skills through practice and leadership training. Leadership training can help young leaders to develop skills required to break through institutional structures. Furthermore, promoting career planning from an early stage and education itself are very important in addition to mentoring and networking. These are essential for leadership and career advancement. A habit of reading leadership books, research, personal reflection and assessment is also helpful in leadership development. Lastly, institutions should also provide more and equal opportunities to workers to enable them develop and achieve their full potential.

\section{Conclusion}

Like the women leaders in any other business organisations, female leaders bring a lot of value to higher education institutions. Unfortunately, most women in academia are appointed in part-time or non-tenured jobs. Unless women in academia believe that their needs will be satisfied from the job to a reasonable degree, they are not going to be willing to work fully for their respective institutions. Institutions need to provide more opportunities to women in academia. If they are not given opportunities for career advancement, it may be very difficult for women to advance and attain highlevel positions. Women's access to leadership opportunities is essential for their career advancement. Therefore, institutions need to examine their practices, policies, rules, norms and procedures to ensure that they help women become more successful in educational leadership roles. 


\section{References}

American Council on Education, 2012. The American college president: 2012 edition. [Online] Available

From: http://www.aacu.org/aacu_news/aacunews12/june12/facts_figures.cfm [Accessed 12 September 2011]

American Council on Education, 2008. Too many rungs on the ladder: faculty demographics and the future leadership of higher education. [Online] Available From:

http://www.acenet.edu/AM/Template.cfm?Section=Home\&TEMPLATE=/CM/Co ntent isplay.cfm\&CONTENTID=33570 [Accessed 12 September 2011]

American Council on Education, 2007. The American college president: Washington, DC

Airo, J. P., Rantanen, J., and Salmela, .T., 2008. Oma ura, paras ura. Helsinki: Talentum. In: Women and Leadership: Factors that influences women's career success. Lahti, E., Bachelor's thesis in international business, Lahti University of applied sciences. [Online] Available From: https://zdoc.site/queue/women-andleadership-factors-that-influence.html [Accessed 23 October 2012]

Baltodano, J. C., Carlson, S., Witcher Jackson, L., and Mitchell, W., 2012. "Networking to leadership in higher education: National and state-based programs and networks for developing women." Advances in Developing Human Resources, Vol. 14(1), 62-78.

Bandura, A., 1997. Self-efficacy: The exercise of control. New York: Freeman

Bandura, A., and Locke, E. A., 2003. Negative self-efficacy and goal effects revisited. Journal of Applied Psychology, Vol, 88(1): 87-99

Bass, B. M., (1990), Bass and Stogdill's Handbook of Leadership: Theory, Research and Managerial Application, 3rd ed., Free Press, New York, NY.

Barsh, J., Cranston, S., and Lewis, G., 2011. How remarkable women lead: The breakthrough model for work and life. Crown Pub

Batliwala, .S., 2011."Feminist leadership for social transformation. Clearing the conceptual cloud". [Online] Available From: http://one365.org/2011/11/21/feminist-leadership-for-social-transformationclearing-the-conceptual-cloud-crea/ [Accessed 15 March 2013]

Birnbaum, R., and Umbach, P. D., 2001. Scholar, steward, and spanner, stranger: The four career paths of college presidents. The Review of Higher Education, Vol. 24(3): 203-217. DIO: 10.1353/RHE.2001.001

Bilen-Green, .C, Froelich, .K.A., and Jacobson, S.W., 2008. The prevalence of women in academic leadership positions and potential impact on prevalence of women in the professorial ranks. Paper presented at the women in engineering proactive network conference, St. Louis, Missouri, June 8-10, 2008

Burns, J. M. (1978). Leadership. New York: Harper \& Row. 
Carter, S. M. and Greer, C. R., 2013. Strategic leadership: Values, styles, and organizational performance. Journal of Leadership \& Organizational Studies, Vol. 20(4): 375-393.

Caliper Research and Development Department, 2014. Women Leaders Research Paper. Caliper. [Online] Available From: http://www.calipermedia.calipercorp.com.s3.amazonaws.com/whitepapers/us/Wo men-Leaders-2014.pdf [Accessed 11 July 2018]

Colorado Women's College, 2013. Benchmarking women's leadership in the United States, 2013. Denver, CO: Colorado Women's College.

Cook, B. J., 2012. The American college president study: Key findings and takeaways. American Council on Education. [Online] Available From: http://www.acenet.edu/the-presidency/columns-and-features/Pages/The-AmericanCollege-President-Study.aspx [Accessed 12 January 2016]

Daft, R. L., Kendrick, M., and Vershinina, N., 2010. Management. Cengage Learning EMEA

Eagly, A. H., Johanessen-Schmidt, M. C., and van Engen, M. L., 2003. Transformational, Transactional and Laissez-Faire Leadership Styles: A MetaAnalysis Comparing Women and Men. Psychological Bulletin, Vol. 129(4):569591.

Eagly, A. H., and Carli, L., 2007. Female leadership advantage and disadvantage: Resolving the contradictions. Psychology of Women Quarterly, 31:1-12

Eagly, A. H., and Wood, W., 2012. Social role theory. In: Handbook of theories in social psychology (pp. 458-476). van Lange, P., Kruglanski, A., and Higgins, E.T., (Eds). [Online] Available From: http://dx.doi.org/10.1037/a0036751 [Accessed 10 July 2018]

Fairchild, C., 2014. Number of fortune 500 women CEOs reaches historic high. Fortune 500. [Online] Available From: http://fortune.com/2014/06/03/number-offortune-500-women-ceos-reaches-historic-high/ [Accessed 17 August 2014]

Fortune 500, 2018. Just 24 female CEOs lead the companies on the 2018 Fortune 500. [Online] Available From: https://www.cnbc.com/2018/05/21/2018s-fortune-500companies-have-just-24-female-ceos.html [Accessed 20 December 2018]

Gagliard, J. S., Espinosa, L. L., Turk, J. M., and Taylor, M., 2017. The American College President Study 2017. [Online] Available From: https://www.acenet.edu/news-room/Pages/Comprehensive-Demographic-Profileof-American-College-Presidents-Shows-Slow-Progress-in-Diversifying-

Leadership-Ranks.aspx [Accessed 24 July 2018]

Grove, J., 2013. Why are there so few female vice-chancellors? The Times Higher Education.

[Online]

Available

From: http://timeshighereducation.co.uk/features/why are there so few-female-vice chancellors/2006576.article [Accessed 23 August 2012]

Hannagan, T., 2008. Management. Concepts and practices. Fifth edition, Great Britain: Pearson Education 
Harrow, A. J., 1993. Power and politics: The leadership challenge. Washington, DC: The College and University Personnel Association

Henning, N., and Jardim, A., 1977. The managerial woman. New York: Anchor Books.

Herzberg, F., 1966. Work and the nature of man. Cleveland: World Publishing Company.

House, R. J., 1971. A path-goal theory of leadership effectiveness. Administrative Science Quarterly, Vol. 16 (1971): 321-339

Hyde, J. S., and Kling, K. C., 2001. Women, motivation, and achievement. Psychology of Women Quarterly, 25, 364-378

Hora, E. A., 2014. Factors that affect women participation in leadership and decisionmaking positions. Asian Business Consortium, Asian Journal of Humanity, Art and Literature, Vol. 1(2): 97-118

Kim, Y. M., and Cook, B. J., 2012. Diversity at the top. The American college president. On Campus with Women, Vol. 41(1), p.1.

Klenke, K. (2011). Women in Leadership: Conntextual Dynamics and Boundaries, Bingely, UK: Emerald Group Publishing Limited

Kouzes, J. M., and Posner, B. Z., (2007). Leadership: The challenge. San Francisco, CA: Jossey-Bass.

Kuchynkova, L., (2013). Managerial Leadership Style in terms of Gender. Social Research, Vol. 4 (33): 18-24.

Lapovsky, L., 2014. Why so few women college presidents? Forbes. [Online] Available From: http://www.forbes.com/sites/lucielapovsky/2014/04/13/why-sofew-women-college-presidents/ [Accessed 13 April 2012]

Lahti, E., 2013. Women and leadership: Factors that influence women's career success- Female leader's reflections on their career success. Bachelor's thesis in international business, Lahti University of Applied Sciences. [Online] Available From: https://zdoc.site/queue/women-and-leadership-factors-that-influence.html [Accessed 23 October 2012]

Laursen, S. L., and Austin, A. E., 2014. Strategic intervention brief \#5: Inclusive recruitment and hiring. In Laursen, S. L., and Austin, A. E., StratEGIC Toolkit: Strategies for Effecting Gender Equity and Institutional Change. Boulder, CO, and East Lansing, MI. [Online] Available From: www.strategictoolkit.org [Accessed 14 June 2017]

Madsen, S. R., 2007. Women university presidents: Career paths and educational backgrounds. Academic leadership Journal, Vol. 5(1): 1-3

Madsen, S. R., Longman, K. A. and Daniels, J. R., 2012. Women's leadership development in higher education: Conclusion and implications for HRD. Advances in Developing Human Resources, 14(1)

Maslow, A. H., 1970. Motivation and personality. Harper and Brothers: New York: NY. 
McClellan, R., and Christman, D., 2008. Living on barbed wire: Resilient women administration in educational leadership programs. Educational Administration Quarterly, Vol. 44(1): 3-29

McGregor, D., 1978. The professional manager, New York: McGraw Hill

McKee, J. M., and Phillips, J. W., 2001. How to motivate the reluctant learner: measurement and relation to career development. Journal of Vocational Behaviour, 58: $98-117$

Morley, L., 2013. The rules of the game: Women and the leaderist turn in higher education. Gender and education, Vol. 25(1): 116-131

National Center for Education Statistics. 2014. Table 301.20, Historical summary of faculty, enrolment, degrees, and finances in degree-granting postsecondary institutions: Selected years, 1869-70 through 2011-12. [Online] Available From: https://nces.ed.gov/programs/digest/d13/tables/dt13_301.20.asp?current=yes [Accessed 18 July 2012]

Oakley, J. G., 2000. Gender-based barriers to senior management positions: Understanding the scarcity of female CEOs. Journal of Business Ethics, 27:321-334

Robbins, S. P., Judge, T. A., and Sanghi, S. (2007). Organizational Behavior, New Delhi: Pearson Education.

Ryan, M., and Deci, E., 2000. Intrinsic and extrinsic motivation: Classic definitions and new directions. Contemporary Education and Psychology 25: 54-67. Doi:10.1006/ceps.1999.1020 [Online] Available From: http://mmrg.pbworks.com/f/Ryan,+Deci+00.pdf [Accessed $30 \quad$ October 2011]

Senge, P. M., 1990. The fifth discipline: The art and practice of the learning organization. New York: Doubleday

Steffen-Fluhr, N., 2006. Advancing women faculty through collaborative research networks. Paper presented at WEPAN conference, Pittsburgh, PA

Supiano, B., 2014. "How small changes are improving gender balance at one business school," Chronicle of Higher Education. [On line] Available From: http://chronicle.com/article/How-Small-Changes-Are/150811/ [Accessed 19 July 2015]

U. S. Department of Education, National Centre for Education Statistics, 2005. Postsecondary institutions in the United States: Fall 2003, Degrees, and Other Awards Conferred: 2002-03. NCES Publication No. 2005-154.

Valdata, P., Mendoza,V., Luma, L., Hawkins, B., Pember, M. A., and Nealy, M. J., 2008. Women redefining leadership. Diverse Issues in Higher Education. 25(3): 16

Walton, K., and McDade, A., 2001. At the top of the faculty: Women as chief academic officers. In: Women administrators in higher education, Nidiffer, J., and Bashaw, C.T., (Eds), Albany, NY: State University of New York Press, 2001, pp. $85-100$

Warner, J., 2014. Fact sheet: The women's leadership gap-women leadership by the numbers:

[Online]

Available

From: 
www.americanprogress.org/issues/women/report/2014/03/07/85457/fact-sheet-thewomens-leadership-gap/ [Accessed 7 March 2014]

West, M. S., and Curtis, J. W., 2006. AAUP faculty gender equity indicators 2006. Washington, D.C: American Association of University Professors. [Online] Accessed From: http://www.aaup.org/NR/rdonlyres/63396944-44BE-4ABA-98155792D93856F1/0/AAUPGenderEquityIndicators2006.pdf [Accessed 9 September 2011]

White, J. S., 2005. Pipeline to pathways. Liberal Education, Vol. 90(1): 22-27

White, K., 2003. Women and leadership in higher education in Australia. Tertiary Education and Management, 19(1).

Wolverton, M., Bower, B. L., and Hyle, A. E., 2009. Women at the top: What women university and college presidents say about effective leadership. Stylus Publishing, LLC.

Young, M. D. and McLeod, S., 2001. "Flukes, opportunities, and planned interventions: Factors affecting women's decisions to become school administrators". Educational Administration Quarterly, Vol. 37(3): 462-502.

\section{Author's Biography}

Sr. Marie Goretti Nakitende (PhD) is a specialist in Education and Leadership. She is currently the Dean, Faculty of Business Administration and Management at Uganda Martyrs University. She is also a lecturer in business and management with specialisation in entrepreneurship, business policy, international business and strategy, business theory and practice, among others. She does research in business, management, entrepreneurship, leadership and education. 